\author{
Ye.S. Sulema ${ }^{1 *}$, D.V. Rvach ${ }^{2}$ \\ ${ }^{1}$ Igor Sikorsky Kyiv Polytechnic Institute, Kyiv, Ukraine \\ ${ }^{2}$ PE "Rvach D.V.", Kyiv, Ukraine \\ *corresponding author: sulema@pzks.fpm.kpi.ua
}

\title{
MODELS OF COMPUTATION FOR DIGITAL TWINS DATA PROCESSING
}

Background. The digital twin is a virtual model of a physical object or process (physical twin) which fully reflects its characteristics in dynamics over a period of time. The concept of digital twin involves the representation, processing, manipulation of multimodal data which characterizes the physical twin. The digital twin data processing requires new models of computation in order to simplify synchronization and aggregation of multimodal data for both behaviour and appearance models of the digital twin.

Objective. The purpose of the research presented in this paper is to develop models of computation for digital twins data processing as well as to fulfil practical implementation of multimodal data synchronization and aggregation for ehealth applications.

Methods. The basic computation model is based on the concept of a multi-image which is considered as a data mathematical model. The notion of a multi-image is defined in the algebraic system of aggregates. In the basic computation model the multi-image is a key abstraction, which is defined at two levels: at the level of input data formation and at the level of formation of multimodal data structure to be processed. The advanced computation model for digital twins includes three stages of synchronization and aggregation, a stage of data processing of both the behavioural model and the appearance model according to the specific task of studying the real-world object (physical twin), and a stage of reproducing the digital twin.

Results. The proposed computation schemes make it easy to synchronize and aggregate heterogeneous data entering into a computer system from multiple sources. The results obtained in the experimental part on this research allow concluding that the computational complexity of multimodal data processing is reduced in comparison with the traditional approach.

Conclusions. Two computation models are proposed for digital twin data processing: a basic computation model and a computation advanced model for digital twins. The key component of these models is multimodal data synchronization and aggregation procedure. A mathematical apparatus of the algebraic system of aggregates is used in the presented research to simplify synchronization and aggregation of multimodal data defined in time.

Keywords: digital twin; model of computation; multimodal data processing; algebraic system of aggregates.

\section{Introduction}

Digital twin technology proposes a new approach to representing and processing a dynamic digital model of a physical object (process), its past, present, and future states and behaviour. According to [1-4], a digital twin is a set of virtual information structures that fully describes the future or actually existing physical object from a micro-level (single element level) to a macro-level (general view, geometric representation, general properties of the object as a whole). Creation of a digital twin for a physical object is a topical task, because the digital twin enables modelling possible behaviour of its physical twin, estimation its future critical states, searching optimal strategies for the physical twin treatment, etc. [2, 3]. Digital twin technology has been developed for engineering and manufacturing, but its key idea may be adapted to many other areas, including e-health.
The digital twin is a virtual model of a physical object or process (physical twin) which fully reflects its characteristics in dynamics over a period of time. The concept of digital twin involves the representation, processing, manipulation of multimodal data that characterise the physical twin, and obtaining certain components of this data as needed to solve the problems of simulation, simulation, optimization of procedures for controlling the physical twin.

The digital twin concept to be applied in an industrial system can enable better product life cycle management. It allows to describe a model of a certain complex object in virtual space created in parallel with the physical system and is gradually enriched with information; this process is based on the so-called "mirrored spaces model" or "information mirroring model" [4].

The term "Digital Twin", as such, was first mentioned in a NASA report containing their future modelling and simulation strategies [1, 3]. The 
NASA program assumes that the digital twin is an integrated multiphysics, multiscale, probabilistic simulation of a research object (e.g., an aircraft) that uses models which are constantly evolving based on data continually coming from sensors of the real object and accumulating to reflect the life cycle of the corresponding object under study - the physical twin. The digital twin needs to be as much realistic as possible and it can represent either one or more interdependent physical twin systems. Analysing the behaviour of the digital twin, it is possible to detect anomalies in the behaviour of the components of the physical twin long before an emergency occurs in the physical twin and, thus, it allows to prevent this emergency in a timely manner. The digital twin integrates sensor data from the embedded system aboard the physical twin, contains information about the research history of the physical twin, etc. Thus, a digital twin is an individualised realistic virtual model of a particular object under investigation a physical twin. For example, the role of digital twins of production systems implementing Industry 4.0 methodology [4] is to use them for prediction and optimization of the production system behaviour at each phase of the life cycle.

\section{Problem statement}

The purpose of the research presented in this paper is to develop models of computation for digital twins data processing as well as to fulfil practical implementation of multimodal data synchronisation and aggregation for e-Health applications.

\section{Analysis of Digital Twin technology}

The digital twin includes both a appearance model of the investigated object and its behavioural model. They are implemented on the basis of the corresponding mathematical models which provide synchronisation between two twins (the virtual object and the real object) at the level of data coming from sensors installed for continuous monitoring of the object of study [2]. There are two types of digital twins: digital twin prototype and digital twin instance [4].

The digital twin prototype is created for a physical object that does not yet exist and will be created after exploring the digital twin. It contains the datasets needed to describe and create a physical twin. These datasets include the requirements for the physical twin, 3D model of the physical object, the specification of the materials and components from which it will be made, etc. The digital twin prototype is implemented by software development.

A digital twin instance is created for an existing object (physical twin) with which this digital twin remains associated throughout the entire life cycle or study cycle of that physical twin. Depending on the task of the study, such a digital twin may contain, in addition to the $3 \mathrm{D}$ model, any behavioural models and may use any data obtained during the monitoring of the physical twin that is determined by a particular problem being solved. The digital twin instance is implemented by software and/or hardware development.

In addition to the digital twin prototype and the digital twin instance, there is a digital twin aggregate [4], which results from the aggregation of a set of digital twins and is used to investigate a particular set (class) of physical objects rather than a single object.

A digital twin environment [4] is a set of hardware and software that supports the process of studying of one or more physical objects. The digital twin environment has two main functions:

Predictive - a digital twin is used to predict the future behaviour of a physical twin. For digital twin prototype, the prediction allows to analyse different options for the implementation of the physical twin even before its physical creation. for digital twin instance, the prediction is intended to predict the possible critical situations for the physical twin and to model the physical twin possible states depending on the variants of external influence (interaction, control) on this physical object or process.

Informational - it allows to get up-to-date information about the investigated object as a whole or its specific characteristics based on information about digital twin instances. It can be used to solve a wide range of research problems.

In terms of the level of integration between a digital twin and a physical twin, there are a digital model, a digital shadow and a digital twin (Fig. 1) [2].

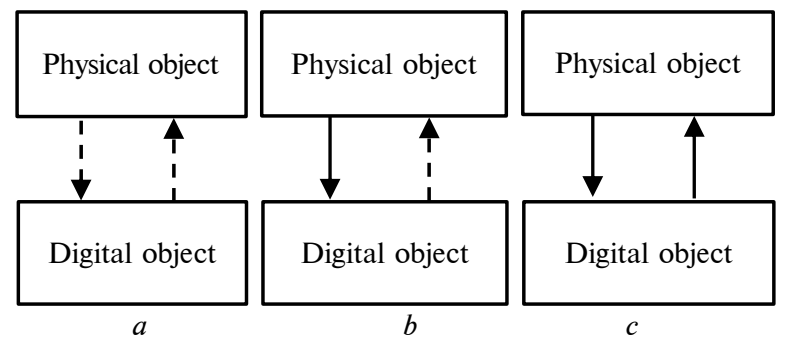

Fig. 1. Levels of integration between a physical object and its digital twin: $a$-digital model, $b$ - digital shadow, $c-$ digital twin; --- manual or automated data transfer, $\longrightarrow$ - automatic data transfer 
A digital model (Fig. 1, a) is a digital representation of an existing or planned physical object that does not use any automated data exchange between a physical object and a digital object. A digital representation may contain a comprehensive description of the physical object. These models may include simulation models, mathematical models, or any other physical object model which do not suppose any automatic data integration. The digital data of existing physical objects can be used to develop such models, but the data is exchanged manually. Changing the state of a physical object has no direct effect on the digital object and vice versa.

A digital shadow (Fig. 1, b) is a digital representation of a physical object, which provides an automated one-way data flow between an existing physical object and a digital object. Changing the state of a physical object changes the state of the digital object, but not vice versa.

A digital twin (Fig. 1,c) is a digital representation of a physical object in which data flows between an existing physical object and a digital object are fully integrated in both directions. In this case, the digital object may also act as a reference instance of the physical object. There may be other objects, physical or digital, that induce state changes in the digital object. Changing the state of a physical object directly changes the state of the digital object and vice versa.

Thus, the variants of the implementation of the digital twin concept depend on the degree of integration between the physical object and its digital representation, purpose, functions, etc. In any case, it is intended to create a visual and behavioural model of the object to be investigated.

An appearance model can only represent a visual appearance of a physical object as a 3D model. However, taking into account the transition from multimedia presentation of real world objects to mulsemedia representation, it is reasonable to develop mulsemedia reproduction models for digital twins which enable human-machine interaction not only at the level of human visual sensations, but also allow inclusion information of other modalities into the process of human perception.

\section{Models of computation}

Basic model of computation. This model is based on the concept of a multi-image which is considered as a mathematical model of data. The notion of a multi-image is defined in the algebraic system of aggregates (ASA) [5, 6]. A multi-image is an aggregate, the first tuple of which is a tuple of temporal data:

$$
\begin{gathered}
I= \\
\llbracket T, M_{1}, \ldots, M_{N} \mid\left\langle t_{1}, \ldots, t_{\tau}\right\rangle, \\
\left\langle a_{1}^{1}, \ldots, a_{n_{1}}^{1}\right\rangle, \ldots,\left\langle a_{1}^{N}, \ldots, a_{n_{N}}^{N}\right\rangle \rrbracket,
\end{gathered}
$$

where $T$ is a set of time values; $M_{j}$ is a set of data values which define a certain information modality; $t_{i}$ is a time value; $a_{i}^{j}$ is a data value; $i \in\left[1, \ldots, n_{j}\right]$; $j \in[1, \ldots, N] ; \tau \geq n_{j} ; N$ is a number of modalities which define the same object.

In the basic model of computation (Fig. 2), the multi-image is a key abstraction, which is defined at two levels: at the level of input data formation and at the level of formation of multimodal data structure to be processed.

At the first level, the multi-image is defined as an aggregate consisting of two tuples: a tuple of time values (timestamps) and a tuple of data of a certain modality. At this level, there is a primary synchronisation of data, namely, the synchronisation of both timestamps and data of the modality for which these timestamps are defined. Thus, the structure of the first-level multi-image is typical, but the second tuple of each of these multi-images belongs to a specific data type (data set) [7,8].

At the second level, the multi-image determines the model of multimodal data aggregation as a single data structure. The second-level multi-image is a mathematical model of a particular abstract data model.

Therefore, the scheme of the basic model of computation includes a two-level hierarchical synchronisation and aggregation procedure. At the first level, synchronisation and aggregation occurs for a pair of tuples "time" - "modality" and at the second level, data of all modalities is synchronised, and their aggregation is completed into a single data structure ready for further processing. This processing is the third layer of the scheme of the basic model of computation.

This scheme of computation makes it easy to synchronise and aggregate heterogeneous data entering into a computer system from multiple sources.

The synchronisation is based on mathematical models, in particular, models of crisp synchronisation and models of fuzzy synchronisation. The pro cessing of the obtained structures of multimodal 


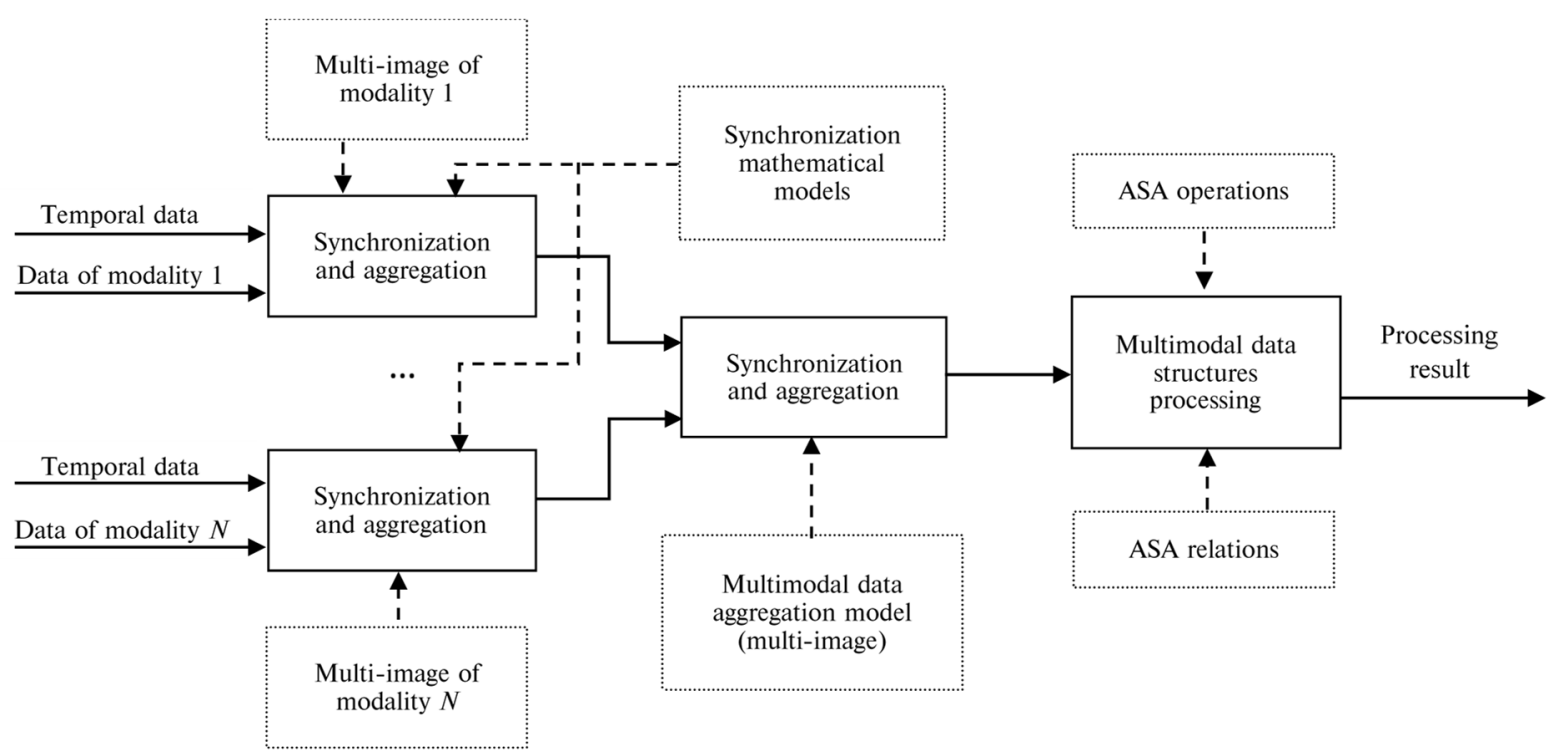

Fig. 2. The scheme of a basic model of computation

data is supposed to be performed using the mathe matical apparatus of the algebraic system of aggregates $[5,6]$, namely, by means of logical operations, ordering operations and relations of aggregates and their components (tuples and elements).

The result of data processing can be a multimodal data structure, a command for an object control, numeric data, textual data, etc.

Advanced model of computation. The processing of multimodal data of a digital twin has its own pe- culiarities due to the fact that the digital twin is defined by two models: the behavioural model and the visual model. Accordingly, the data of each of these models have a different nature and a different source. Therefore, it is reasonable to introduce an additional, intermediate, level of hierarchical synchronisation and aggregation procedure (Fig. 3), where multimodal data are synchronised and aggregated within one model: either behavioural model or appearance model. Let us note that the appearance

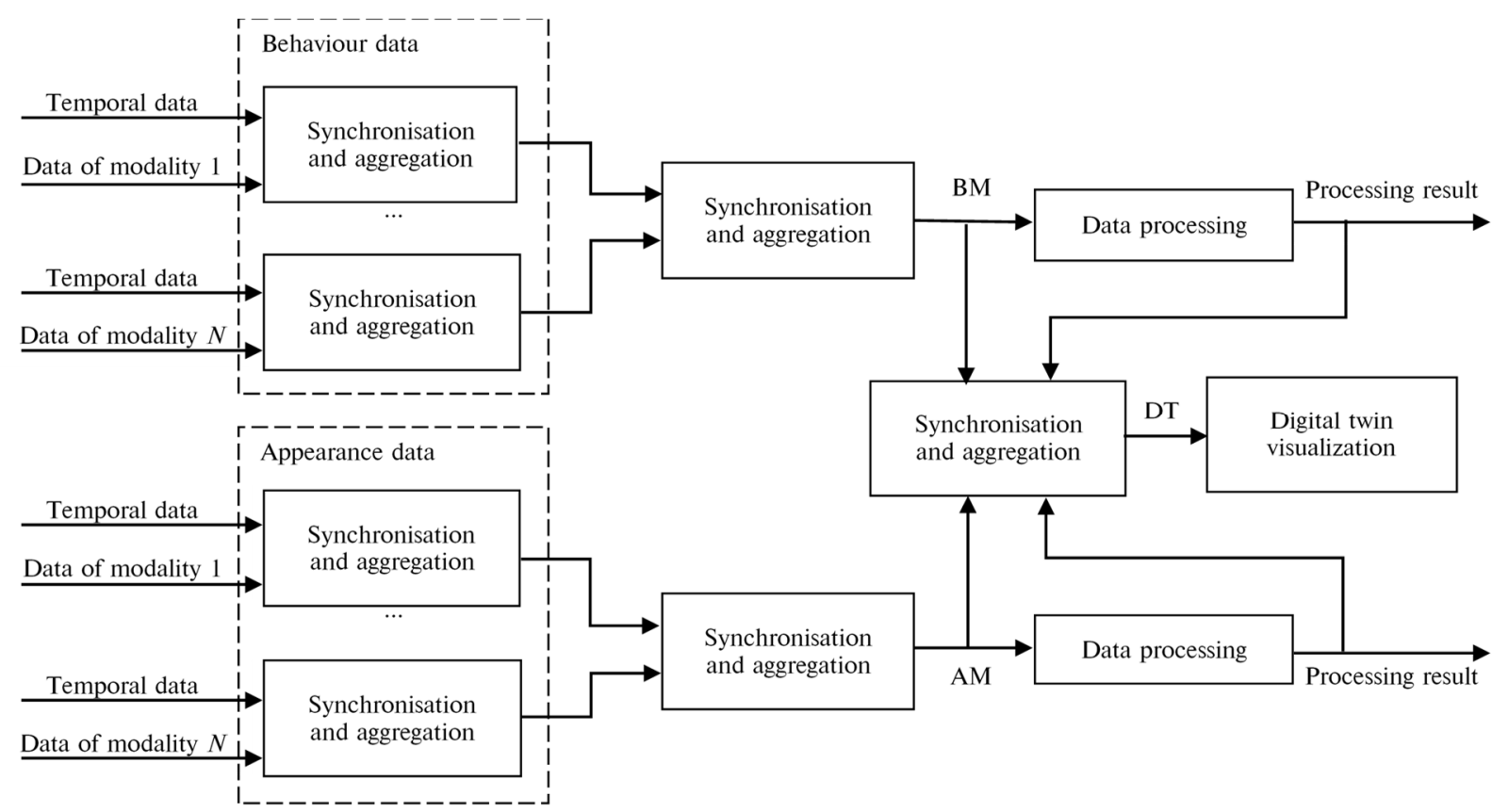

Fig. 3. The scheme of an advanced model of computation 
model not only provides the appearance of the investigated object, but also includes all mulsemedia modalities to provide a comprehensive representation of the real-world object of study.

According to the scheme of an advanced model of computation for digital twins (Fig. 3), which concretises the basic model, at the first stage, synchronisation and aggregation of data of each modality is performed separately. The purpose of this stage is to synchronise data of the same modality, which come from multiple sources. For example, in software systems that implement IoT (Internet of Things) technology in agriculture, soil moisture data may come from multiple sensors located in different locations of the ground area [9].

At the second stage, the formation of both the behavioural model (BM) and the appearance model (AM) of the investigated object is fulfilled (Fig. 3). For each of these models, its multimodal data set is synchronised and aggregated.

At the third stage, the synchronisation and aggregation of the behavioural model and the appearance model data is fulfilled that allows to obtain a complex virtual object, which is a digital twin (DT) of the object of study (Fig. 3). The digital twin creation and reproduction (visualisation) is one of the results of processing the input multimodal data. Besides, the data of each model (behavioural model and visual model) is processed to solve specific problems of the digital twin study. Such specific problems may include the task of predicting the investigated object behaviour, the task of modelling the possible states of the investigated object when the environmental parameters are changed, etc.

Thus, the advanced model of computation for digital twins includes three stages of synchronisation and aggregation, a stage of data processing of both the behavioural model and the appearance model according to the specific task of studying the real world object (physical twin), and a stage of reproducing the digital twin.

\section{Digital twin data synchronisation and aggrega- tion}

Multimodal data synchronisation is a major component of multimodal data structures processing without which all other stages of multimodal data processing are impossible. Mathematical models of data synchronisation enable the further development of algorithms and software for processing the multimodal data structures defined in time.
Based on (1), let us consider two multi-images $I_{1}$ and $I_{2}$ which describe the state of the same investigated object:

$$
\begin{aligned}
& I_{1}=\llbracket T, M_{1} \mid\left\langle t_{i}^{1}\right\rangle,\left\langle a_{i}^{1}\right\rangle \rrbracket_{i=1}^{n_{1}}, \\
& I_{2}=\llbracket T, M_{2} \mid\left\langle t_{i}^{2}\right\rangle,\left\langle a_{i}^{2}\right\rangle \rrbracket_{i=1}^{n_{2}} .
\end{aligned}
$$

It means that one characteristic of the object of study was measured in time moments $\left\langle t_{i}^{1}\right\rangle_{i=1}^{n_{1}}$ that has resulted in obtaining data tuple $\left\langle a_{i}^{1}\right\rangle_{i=1}^{n_{1}}$; another characteristic of this object was measured in time moments $\left\langle t_{i}^{2}\right\rangle_{i=1}^{n_{2}}$, it has resulted in obtaining data tuple $\left\langle a_{i}^{2}\right\rangle_{i=1}^{n_{2}}$. Since $I_{1}$ and $I_{2}$ are describing different aspects of behaviour of the same investigated object, the task is to form a general multi-image $I$, which includes a joint tuple of time values $\bar{t}=\left\langle t_{j}\right\rangle_{j=1}^{n}$ and synchronised data tuples $\left\langle d_{j}^{1}\right\rangle_{j=1}^{n}$ and $\left\langle d_{j}^{2}\right\rangle_{j=1}^{n}$. Tuple $\left\langle d_{j}^{1}\right\rangle_{j=1}^{n}$ includes both elements of the tuple $\left\langle a_{i}^{1}\right\rangle_{i=1}^{n_{1}}$ and empty elements which obtained according to the rule:

$$
d_{j}^{1}= \begin{cases}a_{i}^{1} & \text { if } t_{j}=t_{i}^{1}, \\ \varnothing & \text { otherwise }\end{cases}
$$

Analogously, the tuple $\left\langle d_{j}^{2}\right\rangle_{j=1}^{n}$ includes both elements of the tuple $\left\langle a_{i}^{2}\right\rangle_{i=1}^{n_{2}}$ and empty elements which obtained according to the rule:

$$
d_{j}^{2}= \begin{cases}a_{i}^{2} & \text { if } t_{j}=t_{i}^{2}, \\ \varnothing & \text { otherwise }\end{cases}
$$

The general multi-image $I$ defined in (1) can be obtained as a result of three ASA operations: union, sorting and singling $[5,6]$ :

$$
\begin{gathered}
I=\left(\left(I_{1} \cup I_{2}\right) \uparrow \bar{t}\right) \| \bar{t} \\
=\llbracket T, M_{1}, M_{2} \mid\left\langle t_{j}\right\rangle,\left\langle d_{j}^{1}\right\rangle,\left\langle d_{j}^{2}\right\rangle \rrbracket_{j=1}^{n} .
\end{gathered}
$$

The union operation enables consolidation of data values of multi-images $I_{1}$ and $I_{2}$ in one multiimage $I_{I_{1} \cup I_{2}}$. However, if time tuples in both $I_{1}$ and $I_{2}$, which are $\bar{t}^{1}=\left\langle t_{i}^{1}\right\rangle_{i=1}^{n_{1}}$ and $\bar{t}^{2}=\left\langle t_{i}^{2}\right\rangle_{i=1}^{n_{2}}$ respectively, include equal values, then $I_{I_{1} \cup I_{2}}$ will include duplicates of time values and, therefore, the synchronisation of data tuples $\left\langle a_{i}^{1}\right\rangle_{i=1}^{n_{1}}$ and $\left\langle a_{i}^{2}\right\rangle_{i=1}^{n_{2}}$ 


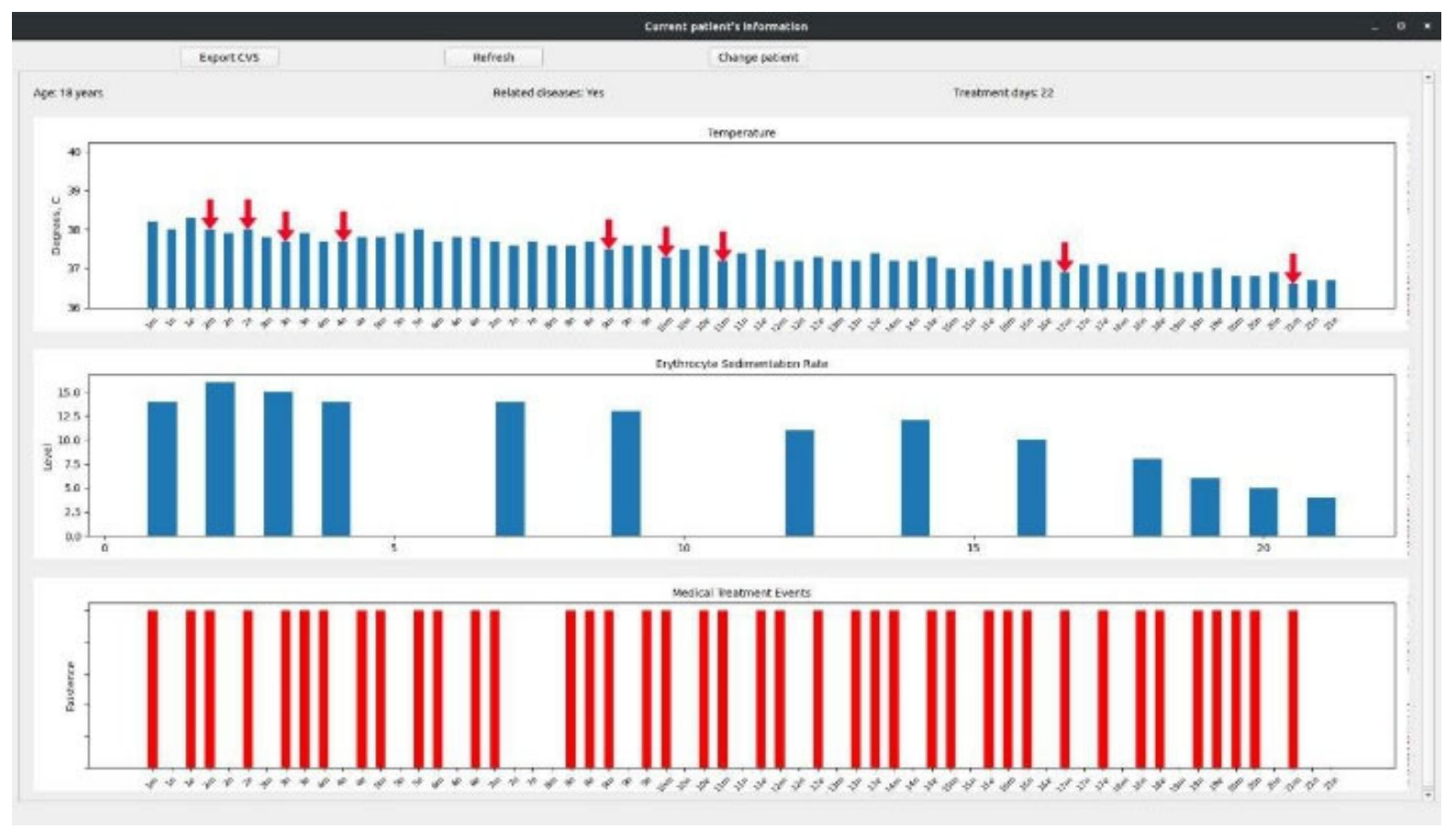

Fig. 4. E-Health application

will be incorrect. To avoid this, it is necessary to order the multi-image $I_{I_{1} \cup I_{2}}$ according to values in the time tuple $\bar{t}=\left\langle t_{j}\right\rangle_{j=1}^{n}$. It can be done by using the sorting operation. Next, the duplicates of time values can be removed by applying the operation of singling.

In this research, the proposed approach to a multi-image creation has been implemented and tested on the example of e-Health application (Fig. 4). The main purpose of developing this application is to prove the concept of multi-image which is the core of both models of computation.

The input data in the experimental part of this research were multimodal data of two types: measured data and events data [10]. In particular, the measured data are patient body temperature values and blood test results (erythrocyte sedimentation rate). The events are the patient's admission to the medication and the physiotherapy procedures. An important prerequisite for each data type is the availability of a timestamp for each value in the multimodal data set. The task was to synchronise the input measured data with each other and to synchronise them with the event data as well as to aggregate the synchronised data for obtaining a multiimage, that is, an ordered set of multimodal data defined over time.
After multimodal data synchronisation and aggregation, the obtained multi-image can be analysed. For example, Fig. 4 shows the correlation (marked with red arrows) between the patient's body temperature and medical treatment events detected by e-Health application according to the proposed approach.

The obtained results showed that the use of the ASA mathematical apparatus makes it easier to determine the degree of influence of events on the measured data. It has a positive effect on reducing the computational complexity of data analysis.

\section{Conclusions}

The paper analyses the concept of digital twins, identifies the types of digital twins and their scope. Two models of computation are proposed for digital twins data processing: a basic model of computation and an advanced model of computation for digital twins. The key component of these models is multimodal data synchronisation and aggregation procedure.

To solve the problem of synchronisation and aggregation of multimodal data defined in time, a mathematical apparatus of the algebraic system of aggregates is used. The carrier of this algebraic system is an aggregate which is a tuple of arbitrary tuples of multimodal data. In particular, the concept 
of multi-image defined in the algebraic system of aggregates was applied for processing of heterogeneous medical data sets, which included both the results of medical investigations and medical events.

The results obtained in the experimental part on this research allow to conclude that the compu tational complexity of multimodal data analysis is reduced in comparison with traditional computational approach. The further research can be focused on the development of time-effective algorithms of data aggregation.

\section{References}

[1] M. Shafto et al., Modeling, "Simulation, information technology \& processing roadmap", in Technology Area 11. NASA, 2010, $32 \mathrm{p}$.

[2] W. Kritzinger et al., "Digital Twin in manufacturing: a categorical literature review and classification", in IFAC-PapersOnLine, vol. 51, no. 11, 2018, pp. 1016-1022. doi: 10.1016/j.ifacol.2018.08.474

[3] E. H. Glaessgen and D.S. Stargel, "The digital twin paradigm for future NASA and U.S. Air Force vehicles", in Proc. 53rd Structures, Structural Dynamics, and Materials Conference: Special Session on the Digital Twin, 2012, 14 p. doi: $10.2514 / 6.2012-1818$

[4] M. Grieves and J. Vickers, "Digital Twin: Mitigating unpredictable, undesirable emergent behavior in complex systems", in Transdisciplinary Perspectives on Complex Systems. Springer, 2017, pp. 85-113. doi: 10.1007/978-3-319-38756-7_4

[5] I. Dychka and Ye. Sulema, "Ordering operations in algebraic system of aggregates for multi-image data processing", KPI Sci. News, no. 1, pp. 15-23, 2019. doi: 10.20535/kpi-sn.2019.1.157245

[6] I. Dychka and Ye. Sulema, "Logical operations in algebraic system of aggregates for multimodal data representation and processing", Naukovi Visti NTUU KPI, no. 6, pp. 44-52, 2018. doi: 10.20535/1810-0546.2018.6.151546

[7] A.A. Fraenkel et al., Foundations of Set Theory. Elsevier, 1973, 415 p.

[8] B.A. Kulik et al., Algebraic Approach to Intellectual Processing of Data and Knowledge. Saint Petersburg, Russia: SPbPU Publ., 235 p., 2010

[9] M. Ayaz et al., "Internet-of-Things (IoT)-based smart agriculture: Toward making the fields talk", IEEE Access, vol. 7, ID 1290564, 2019. doi: 10.1109/ACCESS.2019.2932609

[10] P. Davies and I. Maconochie, "The relationship between body temperature, heart rate and respiratory rate in children", Emergency Med. J., vol. 26, no. 9, 2008. doi: 10.1136/emj.2008.061598

\section{Є.С. Сулема, Д.В. Рвач}

\section{МОДЕЛІ ОБЧИСЛЕНЬ ДЛЯ ОБРОБЛЕННЯ ДАНИХ ЦИФРОВИХ ДВІЙНИКІВ}

Проблематика. Цифровий двійник являє собою віртуальну модель фрізичного об'єкта або процесу (фізичного двійника), яка повністю відображає його характеристики в динаміці протягом певного періоду часу. Концепція цифрового двійника передбачає подання, оброблення, маніпулювання всіма даними, що характеризують фізичного двійника. Оброблення даних цифрового двійника вимагає нових моделей обчислень для спрощення синхронізації та агрегації мультимодальних даних поведінкової та візуальної моделей цифрового двійника

Мета дослідження. Стаття присвячена розробленню моделей обчислень для оброблення даних цисрових двійників і практичній реалізації синхронізації та агрегації мультимодальних даних для застосунків електронної охорони здоров'я.

Методика реалізації. Базова модель обчислень ґрунтується на понятті мультиобразу як математичної моделі даних. Поняття мультиобразу визначене в алгебричній системі агрегатів. У базовій моделі обчислень мультиобраз $є$ ключовою абстракцією, яка визначається на двох рівнях: на рівні формування вхідних даних та на рівні фрормування структури мультимодальних даних, що підлягає обробленню. Основна модель обчислень включає в себе три етапи синхронізації та агрегації, етап оброблення даних поведінкової та візуальної моделей відповідно до конкретної задачі дослідження об’єкта (фізичного двійника) та етап відтворення цифрового двійника.

Результати дослідження. Запропоновані схеми обчислень дають змогу спростити синхронізацію та агрегацію неоднорідних даних, що надходять у комп'ютерну систему з багатьох джерел. Результати, отримані в експериментальній частині цього дослідження, дають можливість зробити висновок, що обчислювальна складність оброблення мультимодальних даних зменшується порівняно з традиційним підходом.

Висновки. Запропоновано дві моделі обчислень для оброблення даних цифрових двійників: базову модель обчислень та модель обчислень для оброблення даних цифрових двійників. Ключовим компонентом цих моделей є синхронізація та агрегація мультимодальних даних. Для розв'язання задачі синхронізації та агрегації мультимодальних даних, визначених у часі, застосовано математичний апарат алгебричної системи агрегатів.

Ключові слова: цифровий двійник; модель обчислень; оброблення мультимодальних даних; алгебрична система агрегатів. 


\section{Е.С. Сулема, Д.В. Рвач}

\section{МОДЕЛИ ВЫЧИСЛЕНИЙ ДЛЯ ОБРАБОТКИ ДАННЫХ ЦИФРОВЫХ ДВОЙНИКОВ}

Проблематика. Цифровой двойник представляет собой виртуальную модель физического объекта или процесса (физического двойника), которая полностью отражает его характеристики в динамике в течение определенного периода времени. Концепция цифрового двойника предусматривает представление, обработку, манипулирование всеми данными, характеризующими физического двойника. Обработка данных цифрового двойника требует новых моделей вычислений для упрощения синхронизации и агрегации мультимодальных данных поведенческой и визуальной моделей цифрового двойника.

Цель исследования. Статья посвящена разработке моделей вычислений для обработки данных цифровых двойников и практической реализации синхронизации и агрегации мультимодальных данных для приложений электронного здравоохранения.

Методика реализации. Базовая модель вычислений основывается на понятии мультиобраза как математической модели данных. Понятие мультиобраза определено в алгебраической системе агрегатов. В базовой модели вычислений мультиобраз является ключевой абстракцией, которая определяется на двух уровнях: на уровне формирования входных данных и на уровне формирования структуры мультимодальных данных, подлежащих обработке. Основная модель вычислений включает в себя три этапа синхронизации и агрегации, этап обработки данных поведенческой и визуальной моделей в соответствии с конкретной задачей исследования объекта (физического двойника) и этап воспроизведения цифрового двойника.

Результаты исследования. Предложенные схемы вычислений позволяют упростить синхронизацию и агрегацию неоднородных данных, поступающих в компьютерную систему из многих источников. Результаты, полученные в экспериментальной части этого исследования, позволяют сделать вывод, что вычислительная сложность обработки мультимодальных данных уменьшается по сравнению с традиционным подходом.

Выводы. Предложены две модели вычислений для обработки данных цифровых двойников: базовая модель вычислений и модель вычислений для обработки данных цифровых двойников. Ключевым компонентом этих моделей являеются синхронизация и агрегация мультимодальных данных. Для решения задачи синхронизации и агрегации мультимодальных данных, определенных во времени, применен математический аппарат алгебраической системы агрегатов.

Ключевые слова: цифровой двойник; модель вычислений; обработка мультимодальных данных; алгебраическая система агрегатов.

Рекомендована Радою

факультету прикладної математики

КПІ ім. Ігоря Сікорського
Надійшла до редакції 16 квітня 2020 року

Прийнята до публікації 05 червня 2020 року 